\title{
ФУНКЦИОНАЛИЗАЦИЯ И ОСОБЕННОСТИ БИОРАСПРЕДЕЛЕНИЯ ФОТОСЕНСИБИЛИЗАТОРОВ НА ОСНОВЕ ХЛОРИНОВ И КОРРОЛОВ
}

\author{
Д.Б. Березин', Д.Р. Каримов', Н.В. Кукушкина', В.В. Макаров', \\ А.В. Кустов ${ }^{2}$, Д.В. Белых ${ }^{3}$, И.В. Коблов ${ }^{4}$, И.Е. Кравченко4, \\ Т.Е. Зорина ${ }^{4}$, В.П. Зорин ${ }^{4}$
}
${ }^{1}$ НИИ макрогетероциклов, Ивановский государственный химико-технологический университет, 153000, Российская Федерация, Иваново, Шереметевский пр-т, 7. 2 Объединенный физико-химический центр растворов, Институт химии растворов им. Г.А. Крестова РАН, 153045, Российская Федерация, Иваново, ул. Академическая, 1.
${ }^{3}$ Институт химии ФИЦ Коми научного центра Уральского отделения РАН, 167000, Российская Федерация, Республика Коми, Сыктывкар, ул. Первомайская, 48. 4 НИЛ биофизики и биотехнологии, Белорусский государственный университет, 220030, Республика Беларусь, Минск, пр-т Независимости, 4.

DOI: 10.19163/MedChemRussia2021-2021-24

E-mail: berezin@isuct.ru

Фотодинамическая терапия (ФДТ), как один из наименее инвазивных подходов к лечению патологий различной этиологии опухолевого или инфекционного происхождения, является прекрасным дополнением, а во многих случаях и альтернативой традиционной химиотерапии [1]. Исследования последних лет показали, что наиболее высокая результативность ФДТ достигается при использовании в качестве фотосенсибилизаторов (ФС) малополярных соединений. Изменение степени полярности может модифицировать параметры фармакокинетики ФС, эффективность инициации апоптотических и некротических повреждений атипичных клеток, относительную результативность повреждения сосудистой системы опухолей и т.д. [2]. В настоящей работе получены новые потенциальные ФС на основе гидрофобных хлоринов и корролов, рассматриваются проблемы агрегации гидрофобных ФС и способы ее преодоления в водных растворах ПАВ [3], особенности распределения пигментов между транспортными белками крови, а также в системе, моделирующей границу раздела фаз «клеточная мембрана - биологическая жидкость» [4], оценивается возможность увеличения результативности лечения онкологических и ряда других заболеваний с использованием вновь синтезированных ФС. Основные выводы приводятся в докладе.

Исследование выполнено за счет гранта РФФИ Бел_а № 20-53-00038.

\section{Литература}

[1] O.I. Koifman, T.A. Ageeva, I.P. Beletskaya, et al., Macroheterocycles, 2020.13(4), 311-467.

[2] L. Yakavets, M. Millard, V. Zorin, H.P. Lassalle, L. Bezdetnaya, J. Contr. Release, 2019. 304, 268-287.

[3] D.B. Berezin, A.V. Kustov, M. A. Krest'yaninov, O.V. Shukhto et al. // J. Mol. Liq. 2019. 283, $532-536$.

[4] A.V. Kustov, D.V. Belykh, N.L. Smirnova, I.S. Khudyaeva, D.B. Berezin, J. Chem. Thermodyn., 2017. 115, 302-306.

[5] A.V. Kustov, T.V. Kustova, D.V. Belykh, I.S. Khudyaeva, D.B. Berezin, Dyes Pigm., 2020. 173, 107948. 